\title{
Evaluation of Rasayana activity of Rudanti (Capparis moonii Wight.) in the Management of Rajayakshma (Pulmonary tuberculosis)
}

\author{
Research Article
}

\section{Lalit Nagar ${ }^{1 *}$, Ringzin Lamo², Mishra J K³ , Dwivedi K N4}

1. PhD Scholar, Department of Dravyaguna, Faculty of Ayurveda,

2. Assistant Professor, Department of Agadtantra, Faculty of Ayurveda, 3. Professor, Department of TB \& Respiratory Diseases, Faculty of Medicine,

4. Professor, Department of Dravyaguna, Faculty of Ayurveda,

Institute of Medical Sciences, Banaras Hindu University, Varanasi-221005, Uttar Pradesh, India.

\begin{abstract}
It is estimated that about $1 / 3$ rd world's population is infected by Mycobacterium tuberculosis. It kills more adults in India than any other infectious diseases. In 2018, India was able to achieve a Total Notification of 21.5 Lakh TB cases of which $25 \%$ was from the private sector. Majority of the TB burden is among the working age group. The $89 \%$ of TB cases come from the age group of $15-69$ years. About $2 / 3$ of the TB cases are Males. Uttar Pradesh, with $17 \%$ of population of the country, is the largest contributor to the TB cases in with $20 \%$ of the total notifications, accounting to about 4.2 Lakh cases (187 cases/ lakh population). Aim and objective: This study was intended to evaluate the rasayana effect of Rudanti (Capparis moonii wight.) as an adjunct to anti-tubercular drugs in the management of Rajayakshma (PTB). Methodology: This is a single blind therapeutic control randomized clinical trial consisting of 100 patients divided in to two groups. Group A patients were treated with DOTS and group B were treated with DOTS along with Rudanti powder 5 gm BD for 6 months. Conclusion: This study shows that by incorporating an herbal rejuvenative in the management of PTB, a chronic debilitating disorder, had an additive effect. Rudanti powder can be easily administered as an adjunct to DOTS. Rudanti has hepatoprotective properties, which remunerate the hepatotoxicity known to cause by DOTS drugs. Improved weight gain in TG patients in comparison to CG indicates the accessory effect of Rudanti.
\end{abstract}

Key Words: Rudanti, Capparis moonii, Rajayakshma, Rasayana, Hepatoprotective, Clinical study.

\section{Introduction}

Yakshma, a disease of ancient origin described in Vedic medicine, could be correlated well with Tuberculosis. This belief-based concept seems to have been well ruminated upon, and eventually entered reason-based Ayurvedic treatises with a redefined name Rajayakshma (Pulmonary tuberculosis -PTB). Many religious, mythological and historical episodes are linked with these dreadful diseases. Rajayakshma (PTB) is considered to be a disease of grave prognosis along with Udara (ascites) and Balashosha (marasmus). (1) Pulmonary tuberculosis remains a major public health problem in developing countries. Tuberculosis is caused by infection with Mycobacterium Tuberculosis (MTB), which is part of a complex of organisms including Mycobacterium bovis (reservoir cattle) and Mycobacterium africanum (reservoir human).

\section{*Corresponding author:}

\section{Lalit Nagar}

PhD Scholar, Department of Dravyaguna

Faculty of Ayurveda, IMS, BHU

Varanasi-221005, India

Email address: drlalitnagar@gmail.com
Special study conducted by WHO estimated that about $1 / 3$ rd world's population is infected by Mycobacterium tuberculosis. It kills more adults in India than any other infectious diseases. Hence, it's a major barrier for socioeconomic development of India. Keeping all this in mind government has developed Revised National Tuberculosis Control Programme, which includes DOTS. It is the main weapon to combat TB today. The main target of this program is $85 \%$ cure rate and $70 \%$ case detection rate. Since 2007 , India has achieved this global target of cure rate and case detection rate. Furthermore, RNTCP has 100\% coverage rate under DOTS. In 2018, India was able to achieve a Total Notification of 21.5 Lakh TB cases of which $25 \%$ was from the private sector. Majority of the TB burden is among the working age group. The $89 \%$ of TB cases come from the age group of 15-69 years. About $2 / 3$ of the TB cases are Males. Uttar Pradesh, with $17 \%$ of population of the country, is the largest contributor to the TB cases in with $20 \%$ of the total notifications, accounting to about 4.2 Lakh cases (187 cases/ lakh population).(2)

In Rajayakshma (PTB), Dhatukshaya (tissue emaciation or loss) is universally accepted as one of the main reasons to initiate pathogenesis. And there is inevitable metabolic dysfunction (Dhatwagni nashana), out of which rasa (tissue fluid), rakta (blood), mansa 
(muscle), meda (adipose tissue) and sukra (generative tissue) are lost. Ultimately, deterioration of immunity (ojokshaya) is evident. In tuberculosis starting from Ojokshaya, sukra, meda dhatus to rasa dhatu is lost preceding each other, which is known as Pratilomakshaya and is an unusual metabolic change.(3)

Many herbal and herbo-mineral drugs are being used for the treatment of Rajayakshma (PTB). Similarly, there is one drug named Rudanti (Capparis moonii wight.) which is widely used as an anti-tubercular drug, but till now no proper research has been done to evaluate the probable mode of its action. But many invitro and in-vivo studies have been done which shows that it has an immunomodulatory(4) and anti-oxidant(5) properties along with its hepato protective activity. In India more than $80 \%$ population depends upon traditional healing therapy. Recently Ministry of AYUSH and Ministry of Health \& Family Welfare have signed $\mathrm{MoU}$ to forge inter-sectoral convergence at the level of policy, planning and program implementation for accelerated response towards "Tuberculosis Free India" initiative.(6)

Poor drug compliance by patients being one of the foremost reasons for frequent relapses and bacterial resistance. Also due to its longer duration and many side effects, it is necessary to develop an adjuvant therapy which will minimize the hazards and help patient to improve the immune status. So present study was intended to evaluate the rasayana effect of Rudanti (Capparis moonii wight.) as an adjunct to antitubercular drugs in the management of Rajayakșma (PTB).

\section{Materials \\ Drug} widely used as an anti-tubercular drug Rudanti first came into reference in soḍhala nighanțu as Vriddhapalitake.(7) Later a detailed description was mentioned in Raja nighantu. Rudanti has katu-tikta rasa, ushna virya, anti-tubercular, anti-microbial, raktapittanashana, properties, anti-asthmatic, expectorant, anti-diabetic and Rasayana actions.(8) Capparis moonii, Wight belongs to the family Capparidaceae frequently found in the konkana regions and grows vigorously in hot semi-arid conditions. Its worldwide distribution is restricted to only Indian Subcontinent i.e. southern India, Sri Lanka exhibiting its endemism.(5)

\section{Collection of Drug}

Trial drug i.e. Rudanti (Capparis moonii Wight.) unripe fruits were collected from the forest of Dist. Sindhudurg, State- Maharashtra in the month of May-June-2018. These fruits were sliced in to small pieces dried in the shade and transported to Varanasi.

\section{Identification}

Botanical Identification of the trial drug was done by Professor Kamal Nayan Dwivedi, Department of Dravyaguna, Faculty of Ayurveda, IMS, BHU.
Sample of collected raw drug was kept in the museum of the department of Dravyaguna with specimen accession number DG/19-20/234.

\section{Preparation of Trial Drug}

Completely dried pieces of unripe Rudanti (Capparis moonii Wight.) fruits were grinded into fine powder of light salmon colour. The advantage of churna kalpana is that, smaller particle size of powder facilitates rapid absorption of drug that leads to higher concentration of drug in the blood in a shorter time thereby the action is produced in a lesser time. This powder was then packed into airtight polybags each packet weighed approx. 300 gms.

\section{Methods \\ CTRI Registration}

This clinical study was registered under the Clinical Trials Registry- India (CTRI), hosted at the ICMR's National Institute of Medical Statistics with CTRI/2018/08/015173 register number.

\section{Ethical consideration}

The study was conducted with good clinical practice and confirmed by the approval of the Institute ethical committee with letter number Dean/2018/EC/ 702, dated 14.02.2018.

\section{Study Design}

It is a single blind therapeutic control randomized clinical trial consisting of 100 newly diagnosed or relapsed cases of pulmonary tuberculosis patients from both the sexes aged between 20 and 70 years and randomly divided into two groups irrespective of age, sex and religion.

Patients attending the O.P.D. and I.P.D. of TB and Chest department and dravyaguna of S.S. Hospital, Varanasi, were randomly selected for the study, irrespective of age, sex, religion, occupation etc. As per the Performa, detailed history and clinical examination and investigation were done and recorded. Subjects were formally informed about the study and those who give written informed consent were enrolled and randomly allotted to the study groups.

Group A: Therapeutic control group (CG)- 50 patients were treated with DOTS.

Group B: Test group (TG) - 50 patients treated with DOTS along with Rudanti powder.

Drug: Rudanti (Capparis moonii Wight.)

Dosage form: Powder

Dose: 5 grams BD

Duration of treatment: 6 months (180 days).

Follow up: 3 follow ups after every 30 days.

Table 1 Inclusion and Exclusion criteria

\begin{tabular}{|l|l|l|l|}
\hline & Inclusion Criteria & & Exclusion criteria \\
\hline i) & $\begin{array}{l}\text { Cases of sputum -ve } \\
\text { and sputum +ve }\end{array}$ & $\begin{array}{l}\text { Extra pulmonary } \\
\text { tuberculosis }\end{array}$ \\
\hline ii) & Relapse cases & ii) & $\begin{array}{l}\text { HIV and Tuberculosis } \\
\text { co-infect }\end{array}$ \\
\hline iii) & Failure cases & iii) & $\begin{array}{l}\text { MDR Tuberculosis } \\
\text { patients }\end{array}$ \\
\hline
\end{tabular}




\begin{tabular}{|l|l|c|l|}
\hline iv) & Age 20-70 year & iv) & $\begin{array}{l}\text { Age below 20 year } \\
\text { and above 70 year }\end{array}$ \\
\hline V) & $\begin{array}{l}\text { With mild pulmonary } \\
\text { infusion }\end{array}$ & V) & $\begin{array}{l}\text { Severely ill and } \\
\text { Pregnant patients }\end{array}$ \\
\hline
\end{tabular}

\section{Criteria for assessment \\ Subjective criteria}

Most of the symptoms and signs of Rajayakshma (PTB) described in Ayurveda are subjective in nature. Following symptoms were taken jwara (Fever), swasa (Dyspnea), kasa (Cough), parshwashool (Pain in the ribs), raktashthivana (Hemoptysis), swarabheda (Hoarseness of voice), atisara (Diarrhea), aruchi (Anorexia), daurbalaya (Weakness). To give results objectively and for statistical analysis, (Normal-0, Mild-1, Moderate-2, Severe-3) scoring pattern was adopted. This score was obtained before and after interval of every month till the end of treatment through statistical analysis and percentage relief was taken out to assess the efficacy of therapy.

\section{Objective Criteria}

It was assessed on the basis of Body weight and Biochemical investigations (CBC, LFT, RFT, Blood sugar fasting and post prandial, Total Protein, serum albumin, HIV, Pregnancy, sputum for AFB, CBNAAT, Liquid culture). Chest X-ray done before during and at the end of the treatment with the follow-up for 3 month in terms of percentage relief and statistical evaluations

\section{Clinical improvement:}

Data obtained from the parameters of assessment, before, during \& after the treatment was utilised to evaluate the overall effect of therapy.

\section{Statistical Analysis}

Paired t-test is used to find out the significant changes from initial to different follow ups and between the follow-ups for within the group comparison test Friedman test was done. $\mathrm{X}^{2}$-test was used to find out the significant difference in the quantitative variables among the study groups. Z- test was applied to find out the significant changes from baseline to different follow ups and between the follow ups.

\section{Observations and Results}

The demographic data in relation to sex, age, socio-economic status and observations on subjective parameters and objective parameters were presented in the

Table 2 indicates that the incidence rate ratio by gender out of the 100 pulmonary tuberculosis patients $38 \%$ was women cases and $62 \%$ were men.

Table 2 Gender ratio in the groups

\begin{tabular}{|c|c|c|}
\hline & Group I & Group II \\
\hline Male & 31 & 31 \\
\hline Female & 19 & 19 \\
\hline
\end{tabular}

Table 3 indicate the out of the total, 100 cases (65 \%) belong to age group below 40 years. This observation supports the knowledge that pulmonary TB (PTB) is commonly a disease of the young adults.

Table 3 Age group ratio

\begin{tabular}{|c|c|c|}
\hline Age Group & Group I & Group II \\
\hline $\mathbf{2 0 - 2 9}$ yrs & 14 & 29 \\
\hline 30-39 yrs & 14 & 8 \\
\hline $\mathbf{4 0 - 4 9}$ yrs & 5 & 4 \\
\hline $\mathbf{5 0 - 5 9}$ yrs & 9 & 5 \\
\hline $\mathbf{6 0 - 6 9}$ yrs & 8 & 4 \\
\hline
\end{tabular}

Table 4 shows socio-economic status has momentous role in the causation of disease. It is fairly clear that almost $100 \%$ of the cases belong to the lower and middle class. These ratios may vary in other studies, since this study was conducted SSL hospital, $\mathrm{BHU}$ most of the visiting patients belongs to lower and middle class population, the ability of whom to afford private care is compromised.

Table 4 Socioeconomic ratio

\begin{tabular}{|c|c|c|}
\hline $\begin{array}{c}\text { Socio-economic } \\
\text { Status }\end{array}$ & Group I & Group II \\
\hline Lower & 19 & 18 \\
\hline Middle & 31 & 32 \\
\hline Upper & 0 & 0 \\
\hline
\end{tabular}

Among the observed 9 symptoms kasa (Cough) was having highest incidence rate (99\%), whereas atisara (diarrhea) had the lowest incidence rate $(0 \%)$. Incidence rate of all the nine symptoms were given in table 5 .

Table 5 Incidence of Clinical Features

\begin{tabular}{|c|c|c|c|}
\hline Symptoms & $\begin{array}{c}\text { Group I } \\
\text { (n) }\end{array}$ & $\begin{array}{c}\text { Group II } \\
\text { (n) }\end{array}$ & Percentage \\
\hline Jwara & 45 & 44 & 89 \\
\hline Swasa & 43 & 45 & 88 \\
\hline Kasa & 50 & 49 & 99 \\
\hline Parshwashool & 44 & 43 & 87 \\
\hline Raktakshtivna & 20 & 15 & 35 \\
\hline Swarabheda & 9 & 15 & 24 \\
\hline Atisara & 0 & 0 & 0 \\
\hline Aruchi & 47 & 49 & 96 \\
\hline Daurbalaya & 48 & 49 & 97 \\
\hline
\end{tabular}

$\mathrm{n}=$ Number of patients.

Among the 9 subjective symptoms, the percentage of relief in the daurbalaya (Weakness) was $97.91 \%$ in the CG whereas in TG it was $100 \%$, after completion of six month trial and in rest of the subjective parameters percentage of relief was $100 \%$ in both the groups so there is no significant difference between the two groups. But when we analyze the percentage of relief after 3 months of treatment there was a significant difference between the group especially in the symptoms of kasa (CG $50 \%$ and TG $100 \%$ ) and daurbalaya (CG $64.58 \%$ and TG $100 \%$ ). Data of all the subjective parameters are shown in table 6. 
Lalit Nagar et.al., Rudanti as a Rasayana drug in Rajayakshma

Table 6- \%age of relief after 3 and 6 months of treatment

\begin{tabular}{|c|c|c|c|c|c|c|c|c|c|}
\hline & \multirow[b]{2}{*}{ Symptoms } & \multicolumn{4}{|c|}{ Group I CG } & \multicolumn{4}{|c|}{ Group II TG } \\
\hline & & $\begin{array}{c}\text { At } 3 \\
\text { months } \\
\text { n= AT } / \\
\text { BT }\end{array}$ & $\begin{array}{c}\% \text { of } \\
\text { Relief }\end{array}$ & $\begin{array}{c}\text { At } 6 \\
\text { months } \\
\text { n= AT } / \\
\text { BT }\end{array}$ & $\begin{array}{c}\% \text { of } \\
\text { Relief }\end{array}$ & $\begin{array}{c}\text { At } 3 \\
\text { months } \\
\text { n= AT/ } \\
\text { BT }\end{array}$ & $\begin{array}{l}\% \text { of } \\
\text { Relief }\end{array}$ & $\begin{array}{c}\text { At } 6 \\
\text { months } \\
\text { n= AT } / \\
\text { BT }\end{array}$ & $\begin{array}{l}\% \text { of } \\
\text { Relief }\end{array}$ \\
\hline 1 & Jwara & $41 / 45$ & 91.11 & $45 / 45$ & 100 & $44 / 44$ & 100 & $44 / 44$ & 100 \\
\hline 2 & Swasa & $39 / 43$ & 90.69 & $43 / 43$ & 100 & $45 / 45$ & 100 & $45 / 45$ & 100 \\
\hline 3 & Kasa & $25 / 50$ & 50 & $50 / 50$ & 100 & $49 / 49$ & 100 & $49 / 49$ & 100 \\
\hline 4 & Parshwashool & $44 / 44$ & 100 & $44 / 44$ & 100 & $42 / 43$ & 97.67 & $43 / 43$ & 100 \\
\hline 5 & Raktakshtivna & $18 / 20$ & 90 & $20 / 20$ & 100 & $15 / 15$ & 100 & $15 / 15$ & 100 \\
\hline 6 & Swarabheda & $08 / 09$ & 88.88 & $09 / 09$ & 100 & $15 / 15$ & 100 & $15 / 15$ & 100 \\
\hline 7 & Atisara & $00 / 00$ & - & $00 / 00$ & - & $00 / 00$ & - & $00 / 00$ & - \\
\hline 8 & Aruchi & $42 / 47$ & 89.36 & $47 / 47$ & 100 & $49 / 49$ & 100 & $49 / 49$ & 100 \\
\hline 9 & Daurbalaya & $31 / 48$ & 64.58 & $47 / 48$ & 97.91 & $49 / 49$ & 100 & $49 / 49$ & 100 \\
\hline
\end{tabular}

$\mathrm{n}=$ Number of patients.

In the investigations of haemoglobin (Fig 1) there was highly significant difference found between the groups $(\mathrm{t}=4.831, \mathrm{p}=0.000)$ after 6 months of treatment. In the TG mean haemoglobin before and after treatment was $11.57 \mathrm{~g} / \mathrm{dl}$ and $13.10 \mathrm{~g} / \mathrm{dl}$ (difference of $1.53 \mathrm{~g} / \mathrm{dl}$ ) whereas in $\mathrm{CG}$ it was $11.25 \mathrm{~g} / \mathrm{dl}$ and 12.02 $\mathrm{g} / \mathrm{dl}$ (difference of $0.77 \mathrm{~g} / \mathrm{dl})$.

Fig 1- Mean Value of Haemoglobin (g/dl)

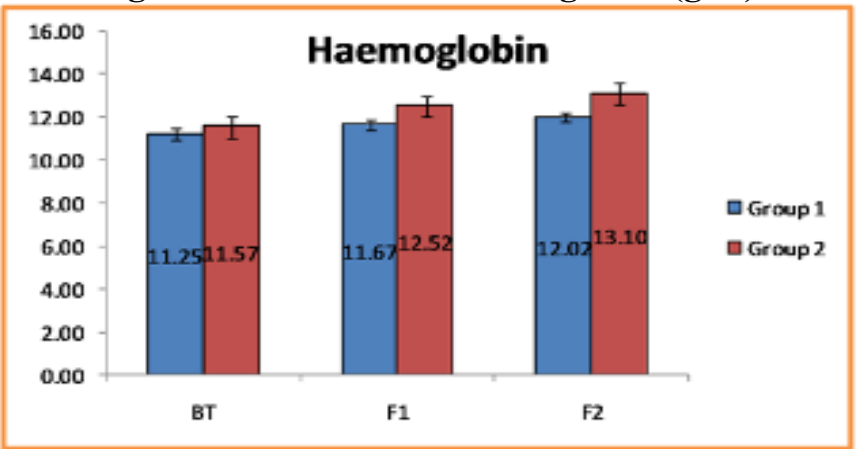

BT (Before start of Treatment), F1 (3 months after the start Treatment), F2 (6 months after the start of treatment)

In the TG mean TLC before and after treatment was 9889.20 and 5408.00 (difference of 4481.20) whereas in CG it was 9320.80 and 5822.00 (difference of 3498.8) which shows that there was considerable decrease in TLC counts in patients of TG which was also statistically significant $(\mathrm{t}=2.137, \mathrm{p}=0.035)$.(Fig 2$)$

Fig 2- Mean Value of Total Leukocyte Count (TLC)

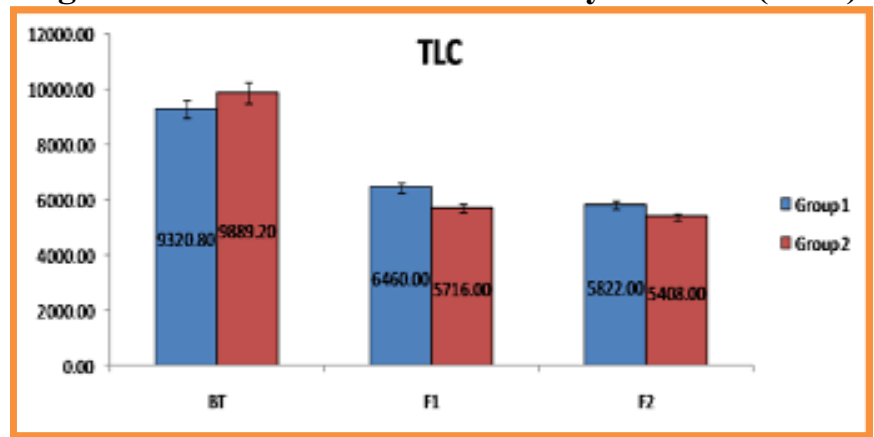

BT (Before start of Treatment), F1 (3 months after the start Treatment), F2 (6 months after the start of treatment)
In the TG mean BMI before and after treatment was 19.76 and 22.34 (difference of 2.58) whereas in CG it was 19.36 and 21.31 (difference of 1.95) which shows that there was statistically significant improvement in BMI in TG patients $(t=2.316, p=0.023)$. (Fig 3)

Fig 3- Mean Value of Body Mass index (BMI)

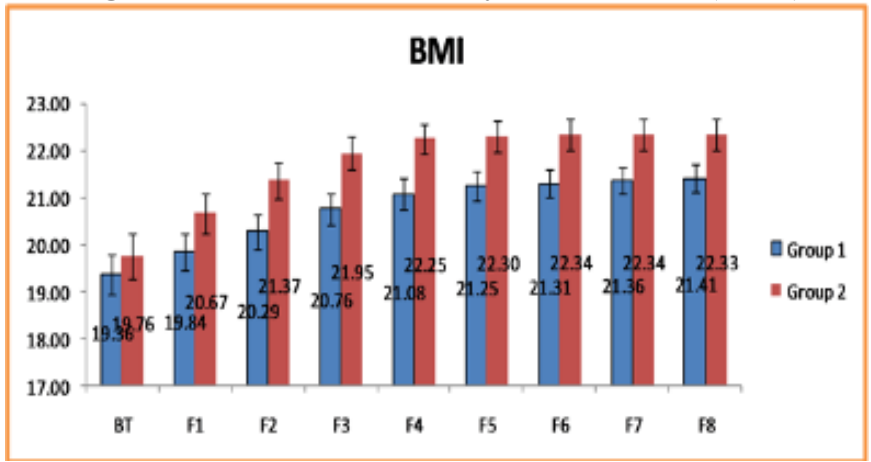

BT (Before start of Treatment), F1 to F8 $(1,2,3,4,5,6,7,8$ months after the start of treatment)

In both groups all patients were reported with sputum conversion within the stipulated time i.e. after intensive phase of treatment of two months HRZE (H-Isoniazid, R: Rifampicin, Z: Pyrazinamide, E: Ethambutol). Significant improvement in the chest $\mathrm{X}-$ rays was found after the completion of six month treatment in both groups.

Drug induced liver injury is a major concern during the treatment of pulmonary tuberculosis in this trial 5 patients $(10 \%)$ from $\mathrm{CG}$ were found to have increased levels in serum bilirubin and other liver enzymes, when compared to the TG only 1 patient ( 2 $\%)$ had disturbed liver function test. These results matches with the other diverse studies which states that overall risk of drug induced liver injury in TB ranges from 5 to as high as $33 \%$. (9)

\section{Discussion}

Rajayakshma (PTB) is described in Ayurveda with specific reference to etiology (Nidana Chatushka) and symptomatology. These correspond to the clinical experience in PTB. The Lakshanas of Kaphaja Krimi (mucosal bacteria) seems to resemble Mycobacterium 
tuberculosis and its effect on the patient.(10) The drug Rudanti possess properties of Rasayana,(11) Krimighna (anti-bacterial) and Kshayahara.(8) The purpose of selecting Rudanti to check its Rasayana activity was fulfilled by these criteria.

Jwara (Pyrexia): There was complete abatement of febrile morbidity in TG patients with in the 30 days of treatment whereas in the CG $42.22 \%$ of patients got relieved of fever. More than $90 \%$ of cases got relieved after 90 days of treatment in CG.

Swasa (Dyspnea): In the first 30 days there was $95.55 \%$ relief in symptoms of dyspnea in the TG patients whereas in the CG $34.88 \%$ of patients got relief. More than $90 \%$ of cases got relieved after 90 days of treatment in CG.

Kasa (Cough): In the first 30 days there was $71.42 \%$ relief in cough gradually diminished and ultimately became occasional and non-productive with easy expectoration within the 60 days of treatment in TG patients, whereas in CG no relief was observed in first 30 days of treatment More than $90 \%$ of cases got relieved after 60 days of treatment in TG and for the same number in CG it took 120 days of treatment.

Parshwashool (Pain in costal and scapular region): There was $90.69 \%$ of relief in symptom observed in TG patients with in the 30 days of treatment and $100 \%$ after 60 days, whereas in CG $9.09 \%$ of relief symptom was observed in 30 days and $100 \%$ after 90 days.

Raktakshtivna (Haemoptysis): There was complete abatement of haemoptysis in TG patients with in the 30 days of treatment whereas in the CG $50 \%$ of patients got relieved in the same time. More than $90 \%$ of cases got relieved after 90 days of treatment in CG.

Swarabheda (Hoarseness of voice): There was $93.33 \%$ of relief in symptom observed in TG patients with in the 30 days of treatment and $100 \%$ relief was observed after 60 days, whereas in CG $12.5 \%$ of relief in symptom was observed in 30 days and more than 90 $\%$ was observed after 90 days. Better relief in TG patients can be attributed to the lessening of cough and easy expectoration within 30 days.

Atisara (Diarrhea): Not a single patient has reported diarrhea during the treatment.

Aruchi (Anorexia): There was $91.83 \%$ of relief in symptom observed in TG patients with in the 30 days of treatment and $100 \%$ relief was observed after 60 days, whereas in CG $2.12 \%$ of relief in symptom was observed in 30 days and more than $90 \%$ was observed after 120 days.

Daurbalaya (Weakness): There was $79.59 \%$ of relief in symptom observed in TG patients with in the 30 days of treatment and $100 \%$ relief was observed after 60 days, whereas in CG $4.16 \%$ of relief in symptom was observed in 30 days and more than $90 \%$ was observed after 120 days. Improve in appetite and increase in weight of the patients in $\mathrm{TG}$ is mainly account for gaining strength.

\section{Probable mode of action}

Basic science research reveals that Rudanti (Capparis moonii Wight.) possesses immunomodulatory (4) and antioxidant(5) properties. Immunomodulation through stimulation or suppression may help in maintaining a disease free state. Agents that activate host defense mechanisms in the presence of an impaired immune responsiveness can provide supportive therapy to conventional chemotherapy. Thus Rudanti improves immunity and enhances the defensive mechanism of the body. Stimulation of the Reticulo Endothelial System (RES) activates the mesenchyme and accelerates healing at the tubercular sites. In turn, this process results in destruction of killer cells and formation of new healthy tissue.(9)

Addition of Rudanti powder to DOTS offers hepatoprotection(12) due to the presence of $\beta$-sitosterol and Rutin and components like stachyhydrin,(14) chebulinic acid derivatives and gallotannins reported for antitussive, antibacterial properties.(13) It has immunomodulatory properties, which create the subjective well-being and cause remarkable changes in the objective parameters.

In patients of Tuberculosis which can be compared with Rajayakshma, there are 3 major events occurring viz. Srotorodh, Rasaraktadi Dhatukshaya and Dhatwagnimandya. Rudanti Choorna is kashaya, tikta in rasa (taste), laghu tikshna guna, katu vipaka and ushna virya which help in removing the srotorodh and dhatwagnimandya, which provided proper nourishment of Dhatus also it is having Rasayana properties which help in building up of superior dhatus. Moreover it is also useful in associated symptoms of Rajayakshma like Kasa (Cough), shwasa (Dyspnea), raktapitta (Hemorrhagic conditions) and showed action fantastically.

Further due to proper nourishment of all Dhatus 'Shukra' is properly formed and thus Vyadhikshamatwa was improved. Rasayan effect helped patient to combat disease and enhanced proper and early recovery.

\section{Limitations}

Due to the limitation of funds necessary bio markers like Tumour necrosis factor- alfa and inter leukin 6 was not taken in to consideration and also sample size was small.

\section{Recommendations}

As in in-vivo studies Rudanti shows immunomodulatory and antioxidant properties and in clinical study test group patients shows better increase in BMI when compare to control group, so a study should be done by taking bio markers like Tumour necrosis factor- alfa and inter leukin 6 in to consideration with large sample size.

\section{Conclusions}

This study shows that by incorporating an herbal rejuvenative in the management of PTB, a chronic debilitating disorder, had an additive effect. Rasayana, plays a supportive and adjuvant role in the management of communicable diseases. Utilization of this modality in the practice of modern medicine appears to be minimal. It is the ardent hope of the 
participants of this study that mainstream medicine will give serious consideration to the availability of other such herb in the vast Pharmacopoeia of Ayurveda, which can substantially enhance the effect of the drugs in its collection.

The purpose of this supportive therapy is to improve the defiance of the patient to damage caused by the tubercle bacilli, and to create an environment in the body unsuitable for proliferation of the bacilli.

The aforesaid properties of the Rudanti are invaluable, not only for correcting low vitality state, but also in the treatment of the disease. Rudanti powder can be easily administered as an adjunct to DOTS. Rudanti has hepatoprotective properties, which remunerate the hepatotoxicity known to cause by DOTS drugs. Improved weight gain in TG patients in comparison to $\mathrm{CG}$ indicates the accessory effect of Rudanti.

\section{References}

1. Debnath P. K. et. al, Adjunct therapy of Ayurvedic medicine with anti tubercular drugs on the therapeutic management of pulmonary tuberculosis. Journal of Ayurveda Integrated Medicine. 2012 JulSep; 3(3); Pg 141-149.

2. ht tps://t b c india.gov.in/index 1.php? lang=1\&level $=1 \&$ sublinkid=4160\&lid=2807 Dated 20-02-2018 18.30 IST

3. Shastri K, Chaturvedi GN. Charak Samhita of Acharya Charaka. Part I and II. Varanasi; Chaukhamba Sanskrit Series; 1969.

4. Doshi GM, Pawar MK, Chavda KH, Quantification of rutin and quercetin by HPTLC/HPLC and in vitro immunomodulatory and anticancer activities of Capparis moonii fruits extracts. International Journal of Basic \& Clinical Pharmacology. 2018; 7(1); 153-161.
5. Yadav P, Malpathak N, Estimation of antioxidant activity and total phenol, flavonoid content among natural populations of Caper (Capparis moonii, Wight) from Western Ghats Region. Indian Journal of Pharmaceutical Education and Research. 2016; 50(3); 495-501.

6. Https://pib.gov.in/pressreleaseiframepage.aspx? PRID=1579413 Dated 08-12-2019 11.30 IST

7. Sharma PV. Shodal Nighantu of Shodal. First edition. Varanasi; Oriental Institute; 1978.

8. Tripathi I. Raj Nighantu of Raja Narhari. Edition 2010. Varanasi; Chowkhambha Krishnadas Academy. 116-117p.

9. Jussi J, Saukkonen, An Official ATS Statement: Hepatotoxicity of Antituberculosis Therapy. American Journal of Respiratory and Critical Care Medicine. 2006; Vol 174; 935-952.

10. Sathya N. Dornala, Snehalatha S. N. Dornala, Clinical efficacy of Bhringarajasava as Naimittika Rasayana in Rajayakshma with special reference to pulmonary tuberculosis. AYU; 2012 Oct-Dec; Issue 4; 523-529.

11. Vidyasagar P S: Sharangdhar Samhita of Sharangdhar. First edition. Varanasi; Chaukhambha Surbharati Prakashan; 2006. 37p.

12. Ali $\mathrm{M}$ et al, Prevention of carbon tetrachlorideinduced hepatotoxicity by the ethanol extract of Capparis moonii fruits in rats. Pharmaceutical Biology; 2004; 42; 286-288.

13. Kanase VG, Jain BB, Yadav P, Evaluation of invitro immunomodulatory activity of aqueous and ethanolic extract of Capparis moonii. Int $\mathrm{J}$ Pharm Bio Sci; 2013; 4(2); 344-352.

14. Kanthamam S, Narayanan CR, Venkatraman K, Isolation of 1 -stachyhydrin and rutin from fruits of Capparis moonii. J Sci Ind Res; 1960; 19; 409-410. 